\title{
PERBANDINGAN TERAPI WUDHU DAN AROMATERAPI TERHADAP KUALITAS TIDUR MAHASISWA KEPERAWATAN SEMESTER V STIKES SURYA GLOBAL YOGYAKARTA
}

Rizca Fatiyah J Rahman ${ }^{1}$, Aris Setyawan ${ }^{2}$

\author{
${ }^{1}$ Mahasiswa Program Studi Ilmu Keperawatan Surya Global Yogyakarta \\ ${ }^{2}$ Dosen Program Studi Ilmu Keperawatan Surya Global Yogyakarta \\ Email:Rizcarahman@gmail.com
}

\begin{abstract}
ABSTRAK
Latar Belakang : Mahasiswa kesehatan yang tinggal di asrama, kegiatan belajarnya dihitung 1 kali 24 jam, beresiko memiliki kualitas tidur yang buruk. Hal ini dapat menyebabkan menurunnya konsentrasi belajar dan prestasi akademik mahasiswa. Solusi yang tepat untuk meningkatkan kualitas tidur mahasiswa santri di asrama adalah melakukan terapi komplementer yang mudah dilakukan secara mandiri.Terapi tersebut ialah terapi wudhu dan aromaterapi. Kedua terapi tersebut menimbulkan efek rileks pada fisiologis dan psikologis pada mahasiswa, sehingga membantu untuk meningkatkan kualitas tidur. Tujuan dari penelitian ini adalah Untuk mengetahui Perbandingan Terapi Wudhu dan Aroma terapi terhadap kualitas tidur Mahasiswa keperawatan semester V STIKes Surya Global Yogyakarta. Metode Penelitian: Penelitian ini menggunakan metode penelitian kuantitatif dengan desain penelitian pre- Eksperimen dengan menggunakan rancangan One Group Pretest- Posttest. Jumlah populasi sebanyak 148 mahasiswa semester V angkatan 2018 di STIKes Surya Global Yogyakarta. Sampel diambil dengan teknik random sampling sebanyak 40 responden terbagi dalam dua kelompok yaitu 20 mahasiswa kelompok terapi wudhu dan 20 mahasiswa kelompok aromaterapi. Analisis data menggunakan uji non parametric Wilcoxon dan mann whitney karena data tidak berdistribusi normal. Hasil Penelitian: Hasil analisis menunjukkan bahwa terdapat penurunan nilai pre post yang signifikan pada kelompok eksperimen dengan nilai $\mathrm{p}$ value $<0,05(\mathrm{p}=0,000)$ dan tidak terdapat perbedan yang signifikan nilai delta kelompok terapi wudhu dan aromaterapi dengan nilai $\mathrm{p}$ value $>0,05$ $(\mathrm{p}=0,883)$.Kesimpulan : Terapi wudhu dan Aromaterapi sama- sama memiliki efek terhadap kualitas tidur sehingga tidak ada perbedaan yang signifikan antara terapi wudhu dan aromaterapi terhadap kualitas tidur Mahasiswa Semester V STIKes Surya Global Yogyakarta.
\end{abstract}

Kata Kunci : Aromaterapi, Kualitas Tidur, Terapi Wudhu

\begin{abstract}
Background: Health students who live in dormitories, their learning activities are counted 1 times 24 hours, are at risk of having poor sleep quality. This can cause a decrease in student concentration and academic achievement. The right solution to improve the sleep quality of students in the dormitory is to do complementary therapies that are easy to do independently. The therapies are ablution therapy and aromatherapy. Both therapies have a relaxing effect on the physiological and psychological aspects of students, thus helping to improve sleep quality. The purpose of this study was to determine the comparison of ablution therapy and aroma therapy on sleep quality for nursing students in the fifth semester of STIKes Surya Global Yogyakarta. Methods: This study used a quantitative research method with a pre-experimental research design using the One Group Pretest-Posttest design. The
\end{abstract}


total population was 148 fifth semester students of class 2018 at STIKes Surya Global Yogyakarta. Samples were taken by random sampling technique as many as 40 respondents divided into two groups, namely 20 students of the ablution therapy group and 20 students of the aromatherapy group. Data analysis used non-parametric Wilcoxon and Mann Whitney tests because the data were not normally distributed. Results: The results of the analysis showed that there was a significant decrease in the pre post value in the experimental group with $\mathrm{p}$ value $<0.05(\mathrm{p}=0.000)$ and there was no significant difference in the delta value of the ablution therapy and aromatherapy groups with $\mathrm{p}$ value> $0,05(p=0.883)$. Conclusion: Ablution therapy and aromatherapy both have an effect on sleep quality, so there is no significant difference between ablution therapy and aromatherapy on sleep quality for the fifth semester students of STIKes Surya Global Yogyakarta.

Keywords: Aromatherapy, Sleep Quality, Wudu Therapy

\section{PENDAHULUAN}

Setiap individu mempunyai kebutuhan yang harus dipenuhi dan dijaga keseimbangannya agar tubuh dapat berfungsi secara normal. Abraham Maslow mengemukakan ada lima hierarki kebutuhan dasar manusia (Five hierarchy of needs), salah satu kebutuhan dasar yang diperlukan manusia adalah tidur.

Istirahat dan tidur merupakan kebutuhan dasar yang dibutuhkan oleh semua orang untuk memperbaiki berbagai sel dalam tubuh. Pola tidur yang tidak adekuat dan kualitas tidur yang buruk dapat mengakibatkan gangguan keseimbangan fisiologis dan psikologis dalam diri seseorang. beberapa faktor yang mempengaruhi pola tidur yaitu usia, stres, lingkungan fisik, diet, obat-obatan, latihan fisik, penyakit, dan gaya hidup (Martini, Roshifanni and Marzela, 2018)

Prevalensi kebutuhan tidur pada usia dewasa muda sangat rendah berdasarkan Center for Disease Control menganalisis data dari Behavioral Risk Factor Surveillance System (BRFSS) didapatkan bahwa Prevalensi Sesuai Usia untuk Durasi Tidur
Singkat $(<7$ jam) Diantara Orang Dewasa Berusia $\geq 18$ Tahun, menurut Negara Bagian, Amerika Serikat, pada tahun 2014. Usia dewasa muda antara merupakan usia pelajar dan mahasiswa. Masalah gangguan tidur, tidak hanya dialami oleh mahasiswa secara umum, mahasiswa kesehatan yang tinggal diasrama atau biasa disebut dengan mahasiswa santri, dapat beresiko mengalami kualitas tidur yang buruk. Kegiatan pengajarannya dihitung 1 kali 24 jam.

Hal ini akan menyita waktu tidur mahasiswa dan mempengaruhi jam tidur serta menurunnya konsentrasi belajar dan prestasi akademik mahasiswa. Solusi yang tepat untuk meningkatkan kualitas tidur mahasiswa santri di asrama adalah melakukan terapi komplementer yang mudah dilakukan secara mandiri.Terapi tersebut ialah terapi wudhu dan aromaterapi. Mekanisme terapi wudhu Mekanisme dimulai dari air wudhu yang digunakan, dapat bermanfaat dalam mendinginkan ujung saraf jari tangan dan kaki yang akan memberikan manfaat dalam memantapkan konsentrasi dan membuat tubuh menjadi rileks. Saat melakukan 
gerakan wudhu akan memberikan efek masage (pijatan) pada anggota tubuh yang dibasuh, efek masage dapat mendorong tubuh untuk mengeluarkan hormon endorfin yang memberikan perasaan nyaman (Dwi Lestari and Rofiqul Minan, 2018).

Sedangkan mekanisme aromaterapi ialah dimulai dari aroma yang dihirup memasuki hidung dan berhubungan dengan silia, penerima di dalam silia dihubungkan dengan alat penghirup yang berada di ujung saluran bau. Bau-bauan diubah oleh silia menjadi impuls listrik yang dipancarkan ke otak melalui sistem penghirup. Semua impulsi mencapai sistem limbik di hipotalamus selanjutnya akan meningkatkan gelombang alfa di dalam otak dan akan membantu kita untuk merasa rileks. Pada intinya manfaat dari kedua terapi tersebut ialah menimbulkan efek rileks pada fisiologis dan psikologis mahasiswa, sehingga membantu untuk meningkatkan kualitas tidur. Tujuan dari penelitian ini yaitu untuk mengetahui adanya perbandingan terapi wudhu dan aromaterapi terhadap kualitas tidur mahasiswa keperawatan semester V stikes surya global Y

\section{Metode}

Penelitian ini menggunakan metode penelitian kuantitatif dengan desain penelitian pre- Eksperimen dengan menggunakan rancangan One Group Pretest-Posttest. Populasi dalam penelitian ini adalah seluruh mahasiswa keperawatan semester V STIKes Surya Global Yogyakarta dengan jumlah 148 mahasiswa. Jumlah sampel sebanyak 40 mahasiswa yang dikategorikan atau ditempatkan dalam kelompok secara acak (random assignment), yaitu 20 orang sebagai kelompok terapi wudhu dan 20 orang sebagai kelompok aromaterapi. Teknik pengambilan sampel yaitu dengan simple random sampling dengan cara mengambil secara acak nomor urut presensi mahasiswa yang digulung dengan kertas. Penelitian ini telah lulus uji etik dengan

No.e

\section{KEPK/POLKESYO/0222/III/2021.}

Penelitian dilakukan pada malam hari sebelum tidur, selama 3 hari berturut- turut. Responden diberikan terapi wudhu sesuai lembar observasi wudhu (checklist) dan aromaterapi dengan menggunakan aroma esensial peppermint dengan cara inhalasi selama 5-10 menit di kamar asrama mahasiswa STIKes Surya Global Yogyakarta. Pengukuran skor kualitas tidur diukur menggunakan Intrumen Pittsburg Sleep Quality Index (PSQI), saat sebelum diberikan terapi dan diukur kembali setelah dilakukan terapi dengan menggunakan instrumen yang pada kelompok terapi wudhu dan aromaterapi. Teknik Analisis Data menggunakan uji normalitas data dalam penelitian ini menggunakan uji Shapiro Wilk karena jumlah sampel < 50. Data dikatakan normal apabila $\mathrm{P}$ value $>0,05$. Setelah itu dialkukan analisa bivariat dengan uji non parametric wilcoxon karena data tidak berdistribusi normal. Pada data untuk menentukan perbandingan selisih skor kualitas tidur pada kelompok terapi 
wudhu dan aromaterapi, peneliti menggunakan Uji Mann Whitney.

\section{Hasil}

Karakteristik responden terdiri dari jenis kelamin dan usia. Distribusi frekuensi karakteristik responden dapat dilihat pada tabel 1 .

\section{Tabel 1}

Distibusi Karakteristik Responden

Mahasiswa Keperawatan Semester V Di

STIKes Surya Global Yogyakarta

Tahun $2020(n=40)$

\begin{tabular}{clcc}
\hline No & Karakteristik Responden & F & \% \\
\hline 1 & Usia 19tahun & 6 & $15 \%$ \\
& 20 tahun & 26 & $65 \%$ \\
& 21 tahun & 8 & $20 \%$ \\
\hline 2 & Jenis Kelamin Laki- laki & 0 & $0 \%$ \\
& Perempuan & 40 & $100 \%$ \\
\hline 3 & Asrama Darul Hijrah & 20 & $50 \%$ \\
& Darussalam & 20 & $50 \%$ \\
\hline
\end{tabular}

Sumber : Data Primer 2021

Uji Normalitas Data pada variable kualitas tidur Kelompok Terapi Wdhu dan Aromaterapi dapat dilihat pada tabel 2.

\section{Tabel 2}

Uji Normalitas Shapiro Wilk test pada variable kualitas tidur Mahasiswa di STIKes Surya Global Yogyakarta pada Kelompok Terapi Wdhu dan Aromaterapi

\begin{tabular}{lccccc}
\hline Kelompok & \multicolumn{4}{l}{ Shapiro Wilk } \\
\cline { 2 - 6 } & & Statistic & Df & Sig & keterangan \\
\hline Terapi Wudhu & Pretest & 0.972 & 20 & 0.787 & Normal \\
\cline { 2 - 6 } Aromaterapi & Posttest & 0.789 & 20 & 0.001 & Tidak Normal \\
\cline { 2 - 6 } & Pretest & 0.984 & 20 & 0.977 & Normal \\
\cline { 2 - 6 } & Posttest & 0.828 & 20 & 0.002 & Tidak Normal \\
\hline
\end{tabular}

*P Value $>0.05$ berdasarkan pada Shapiro Wilk

Kualitas tidur sebelum dan sesudah dilakukan terapi wudhu pada mahasiswa semester V dapat dilihat pada tabel 3.

\section{Tabel 3}

Kualitas tidur sebelum dan sesudah dilakukan terapi wudhu pada mahasiswa semester V Di STIKes Surya Global Yogyakarta

\begin{tabular}{|c|c|c|c|c|c|}
\hline \multirow{2}{*}{\multicolumn{2}{|c|}{ Kelompok }} & \multicolumn{4}{|c|}{ Wilcoxon } \\
\hline & & $\mathrm{n}$ & Mean & $\mathrm{Z}$ & $\begin{array}{l}\text { Sig. (2- } \\
\text { tailed) }\end{array}$ \\
\hline $\begin{array}{l}\text { Terapi } \\
\text { Wudhu }\end{array}$ & $\begin{array}{c}\text { Pretest } \\
\text { Posttest }\end{array}$ & 20 & $\begin{array}{l}8.35 \\
4.00\end{array}$ & -3.936 & 0,000 \\
\hline
\end{tabular}

*P Value $<0.05$ berdasarkan pada uji Wilcoxon

Kualitas tidur sebelum dan sesudah dilakukan Aromaterapi pada mahasiswa semester V dapat dilihat pada tabel 4 .

Tabel 4

Kualitas tidur sebelum dan sesudah dilakukan Aromaterapi pada mahasiswa semester V Di STIKes Surya Global Yogyakarta

\begin{tabular}{lccccc}
\hline Kelompok & \multicolumn{4}{c}{ Wilcoxon } \\
\hline & $\mathrm{n}$ & Mean & Z & $\begin{array}{l}\text { Sig. (2- } \\
\text { tailed) }\end{array}$ \\
\hline \multirow{2}{*}{ Aromaterapi $\begin{array}{c}\text { Pretest } \\
\text { Posttest }\end{array}$} & 20 & $\begin{array}{r}8.15 \\
3.19\end{array}$ & -3.848 & 0,000
\end{tabular}

*P Value $<0.05$ berdasarkan pada uji Wilcoxon.

Perbandingan terapi wudhu dan aromaterapi terhadap kualitas tidur mahasiswa keperawatan semester $\mathrm{V}$ dapat dilihat pada tabel 5.

Tabel 5

Perbandingan terapi wudhu dan aromaterapi terhadap kualitas tidur mahasiswa keperawatan semester V Di

STIKes Suya Global Yogyakarta

\begin{tabular}{lccc}
\hline Kelompok & \multicolumn{3}{c}{ Mann whitney } \\
\cline { 2 - 4 } & Pretest Posttest & 20 & Mean 'Value \\
\hline Terapi & 20.78 \\
Wudhu & \multicolumn{2}{c}{0,883} \\
\hline \hline Aromaterapi & Pretest Posttest & 20 & 20.23 \\
\hline P Value $<0.05$ berdasarkan uji Man Whitney
\end{tabular}




\section{Pembahasan}

\section{Karakteristik responden}

Pada usia, penelitian dilakukan terhadap 40 responden, didapatkan hasil bahwa mayoritas responden dengan usia 20 tahun sebanyak 26 orang dengan presentase $(65 \%)$. Prevalensi kebutuhan tidur pada usia dewasa muda sangat rendah berdasarkan Center for Disease Control menganalisis data dari Behavioral Risk Factor Surveillance System (BRFSS) didapatkan bahwa Prevalensi Sesuai Usia untuk Durasi Tidur Singkat (<7 jam) Diantara Orang Dewasa Berusia $\geq 18$ Tahun, menurut Negara Bagian, Amerika Serikat, pada tahun 2014. Hal ini juga sejalan dengan penelitian yang dilakukan oleh Dwindi Arfiyan (2018), mengatakan bahwa sebanyak 160 responden mahasiswa keperawatan di Universitas Aisiyah Yogyakarta, 138 mahasiswa (86,3\%) memiliki kualitas tidur yang buruk. Karena kegiatan mengerjakan tugas mahasiswa yang membuat mereka tidur lebih lambat dan bangun lebih awal. Sedangkan karakteristik responden menurut jenis kelamin, didapatkan hasil undian dengan menggunakan teknik random sampling mendapatkan seluruh sampel berjenis kelamin perempuan sebanyak 40 orang (100\%).

Hal ini menunjukkan bahwa minat perempuan dalam pendidikan keperawatan memang jauh lebih besar dari pada lakilaki. Profesi keperawatan yang didominasi kaum wanita disebabkan karena sikap dasar wanita yang identik sebagai sosok yang ramah, sabar, telaten, lemah lembut, berbelas kasih, dan gemar bersosialisasi. Kaum wanita dianggap memiliki naluri keibuan dan sifat caring terhadap orang lain (Arifin, 2020).

Selain karena ketersediaan responden yang lebih banyak wanita juga disebabkan karena wanita lebih beresiko mengalami penurunan fungsi kognitif seperti kualitas tidur yang buruk disebabkan karena adanya peranan dari hormone endogen dalam perubahan fungsi kognitif. Untuk karakteristik responden berdasarkan asrama mahasiswa STIKes Surya Global Yogyakarta, didapatkan hasil penelitian sebanyak 20 orang diasrama Darul Hijrah dan 20 orang diasrama Darussalam dengan presentase masing-masing adalah 50\%. Selain pada gaya hidup, kondisi lingkungan juga dapat mempengaruhi kualitas tidur. Misalnya rangsangan sensorik dari lingkungan seperti bunyi, cahaya, pergerakan, dan bau dapat mempengaruhi insisi dan kualitas tidur. Gangguan tidur sering disebabkan lingkungan yang bising atau oleh karena suhu lingkungan yang tidak nyaman.

Pertukaran jam kerja yang tidak teratur sering menyebabkan gangguan siklus tidur, seperti halnya yang juga terjadi pada jetlag akibat bepergian ke tempat yang mempunyai waktu yang tidak cocok dengan daerah asal. Pergantian ketinggian yang 
signifikan juga dapat menyebabkan gangguan tidur (Lubit,2012).

Kualitas tidur mahasiswa keperawatan semester V STIKes Surya Global Yogyakarta sebelum dan sesudah diberikan terapi wudhu

Hasil penelitian kualitas tidur mahasiswa sebelum dan sesudah diberikan intervensi pada kelompok wudhu selama 3 hari berturut- turut saat malam hari sebelum tidur dapat meningkatkan kualitas tidur mahasiswa. Hal ini dibuktikan dengan uji wilcoxon diperoleh nilai $\mathrm{p}<0,05(\mathrm{p}=0,000)$ yang artinya terdapat perbedaan yang signifikan antara skor kualitas tidur mahasiswa pada pre-posttest kelompok terapi wudhu. Skor kualitas tidur mengalami penurunan dari nilai rata-rata 8.35 dan menjadi 4.00. Hasil dapat dilihat di Tabel 3.

Secara anatomis, anggota wudhu terletak pada ujung- ujung tubuh (kepala, tangan, kaki). Bagian- bagian tersebut paling banyak mengandung susunan tulang dan sendi, serta banyak melakukan gerakangerakan. Dalam kaitannya dengan ritual wudhu, dimana membasuh anggota wudhu 1 - 3 kali. Jumlah tulang manusia dewasa ada 206 ruas (Henry Netter, 1906). Faktanya, dibagian tubuh terdapat serabut saraf, arteri, vena, dan pembuluh limfa. Menggosok sela- sela jari memperlancar aliran darah perifer (terminal) yang menjamin pasokan makanan dan oksigen. Selain itu, serabut saraf juga secara langsung distimulasi oleh tindakan kita menggosok sela- sela jari. Ujung jari sampai telapak tangan adalah bagian paling sensitif, karena paling banyak mengandung simpul reseptor saraf. Tiap $1 \mathrm{~cm}^{2}$ kulit di daerah itu terdapat 120- 230 ujung saraf peraba

(Sagiran, 2018). Basuhan air wudhu, dalam konsep pengobatan modern, disebut dengan Hydromassage, yaitu pijat dengan memanfaatkan air sebagai media pengobatan. System metabolisme tubuh manusia terhubung dengan jutaan saraf yang ujungnya tersebar disepanjang kulit. Membasuh anggota tubuh dalam wudhu akan memberikan efek positif bagi anggota tubuh lainnya. Selain itu, Dr. Ahmad Syauqy Ibrahim, peneliti bidang penyakit dalam dan penyakit jantung di London mengatakan, "Mencelupkan anggota tubuh dalam air akan mengembalikan tubuh yang lemah menjadi kuat, mengurangi kekejangan pada saraf dan otot, menormalkan detak jatung, kecemasan, dan insomnia (susah tidur)" (El-Bantanie, 2010).

\section{Kualitas tidur mahasiswa keperawatan semester V STIKes Surya Global Yogyakarta sebelum dan sesudah diberikan aromaterapi}

Hasil penelitian pada tabel 4, kualitas tidur mahasiswa sebelum dan sesudah diberikan aromaterapi pada kelompok aromaterapi dengan cara inhalasi selama 510 menggunakan aromaterapi peppermint 
dapat membuat responden merasa rileks dan mudah untuk memulai tidur sehingga dapat meningkatkan kualitas tidur, diperoleh nilai dari uji Wilcoxon dengan Pvalue $<0,05 \quad(p=0,000)$ maka artinya terdapat perbedaan yang signifikan antara skor kualitas tidur mahasiswa pada preposttest aromaterapi. Skor kualitas tidur mengalami penurunan dari nilai rata-rata 8.15 menjadi 3.95.

Penanganan masalah gangguan tidur secara non farmakologi salah satunya dengan cara pemberian aromaterapi. Aromaterapi merupakan cara pengobatan penyakit dengan menggunakan bau-bauan yang umumnya berasal dari tumbuhtumbuhan serta berbau harum, gurih, dan enak yang disebut minyak asiri. Aromaterapi suatu cara perawatan tubuh dan penyembuhan penyakit dengan minyak essensial (essential oil). Pada hal ini responden pada kelompok intervensi telah melakukan inhalasi aromaterapi peppermint dengan baik sesuai checklist dan di kontrol oleh peneliti di asrama mahasiswa STIKes Surya Global Yogyakarta. Rangsangan penciuman seperti peppermint, ketika disajikan selama tidur, menghasilkan respons fisiologis pada orang dewasa muda, peppermint juga mengurangi kelelahan dan memperbaiki suasana hati serta dinilai lebih menyenangkan, intens, merangsang, dan menggembirakan (Goel, Kim and Lao, 2006).
Sesuai dengan mekanismenya, aroma minyak esensial dihirup oleh seseorang, maka molekul aroma tertangkap oleh saraf sensori pada membrane olfactorius, kemudian secara elektrikal impuls-implus diteruskan menuju pusat emosi pada lobus limbik. Limbik lobus terdiri dari hippocampus serta amigdala yang secara langsung dapat mengaktifkan hipotalamus untuk pengaturan pengeluaran hormon dalam tubuh, memberi efek sedatif atau relaksasi. Efek tersebut yang dapat meningkatkan kenyamanan dan meningkatkan kualitas tidur. (Putri and Amalia, 2019). Peppermint dari keluarga Lamiaceae. Menthol adalah salah satu senyawa kimia peppermint. Menthol mempengaruhi reseptor Kappa Opioid, memblokir transmisi sinyal nyeri, dan mengurangi nyeri. Selain itu, peppermint mempengaruhi hipotalamus dengan merangsang jalur penciuman dan menurunkan hormon pelepas kortikotropin, yang mengurangi sekresi kortisol dari kelenjar adrenal, sehingga mengurangi kecemasan (Hamzeh, SafariFaramani and Khatony, 2020).

Perbandingan terapi wudhu dan aromaterapi terhadap kualitas tidur mahasiswa keperawatan semester $\mathrm{V}$ STIKes Surya Global Yogyakarta

Berdasarkan hasil penelitian pada tabel 4. 5, diperoleh nilai $\mathrm{p}$ value $>0,05(\mathrm{p}=0,883)$ maka artinya tidak terdapat perbedaan yang signifikan antara nilai delta kualitas tidur 
pada kelompok terapi wudhu dan aromaterapi mahasiswa keperawatan semester V STIKes Surya Global Yogyakarta. Hasil dapat dilihat di tabel 5.

Hasil menunjukkan keefektifan kedua terapi dalam meningkatkan kualitas tidur mahasiswa keperawatan semester V STIKes Surya Global Yogyakarta. Kedua kelompok tersebut merespon stimulus sebagai suatu proses relaksasi yang baik. Nilai rata-rata kualitas tidur pada kedua kelompok cenderung menurun. Jadi dalam penelitian ini dapat peneliti simpulkan bahwa terapi komplementer wudhu dan aromaterapi sama-sama efektif meningkatkan kualitas tidur mahasiswa keperawatan semester V STIKes Surya Global Yogyakarta.

Terapi wudhu efektif karena memiliki mekanisme seperti hydromassage, yaitu pijat yang memanfaatkan air sebagai media pengobatan. Mekanisme air wudhu yang digunakan, bermanfaat dalam mendinginkan ujung saraf jari tangan dan kaki yang akan memberikan manfaat dalam memantapkan konsentrasi dan membuat tubuh menjadi rileks. Saat melakukan gerakan wudhu akan memberikan efek masage (pijatan) pada anggota tubuh yang dibasuh, efek masage dapat mendorong tubuh untuk mengeluarkan hormon endorfin yang memberikan perasaan nyaman, lebih mudah untuk memulai tidur sehingga kualitas tidur menjadi baik (Dwi Lestari and Rofiqul Minan, 2018).

Selain terapi wudhu yang dapat mengobati gangguan tidur aromaterapi yang merupakan terapi komlementer juga dapat mengobati gangguan tidur seperti insomnia. Esensial peppermint yang digunakan secara olfaction atau di hirup selama 5 - 10 menit sebelum tidur dapat mencetuskan respon pada system limbik di otak. Pemberian aroma terapi secara inhalasi akan menstimulasi reseptor silia saraf olfactorius yang berada di epitel olfactory untuk meneruskan aroma tersebut ke bulbus olfactorius melalui saraf olfactorius yang berhubungan dengan sistem limbik (Setyawan and Oktavianto, 2020). Sistem limbik menerima semua informasi dari sistem pendengaran, sistem penglihatan, dan sistem penciuman. Limbik adalah struktur bagian dalam dari otak yang berbentuk seperti cincin yang terletak di bawah korteks serebri. Bagian terpenting dari sistem limbik yang berhubungan dengan aroma adalah amygdala dan hippocampus.

Amygdala merupakan pusat emosi dan hippocampus yang berhubungan dengan memori kemudian melalui hipotalamus sebagai pengatur maka aroma tersebut akan dibawa kedalam bagian otak yang kecil tetapi signifikannya yaitu nukleus raphe. Efek dari nukleus raphe yang terstimulasi yaitu terjadinya pelepasan serotonin yang merupakan neurotransmitter yang mengatur permulaan untuk tidur (Ramadhan and 
Zettira, 2017).

\section{Kesimpulan}

Terapi wudhu dan Aromaterapi sama- sama memiliki efek terhadap kualitas tidur sehingga tidak ada perbedaan yang signifikan antara terapi wudhu dan aromaterapi terhadap kualitas tidur Mahasiswa STIKes Surya Global Yogyakarta.

\section{Ucapan Terimakasih}

Penulis mengucapkan terima kasih kepada Direktur STIKES Surya Global Yogyakarta dan Ketua Lembaga Penelitian dan Pengabdian Masyarakat yang telah memberikan dukungan dalam penyelesaian publikasi ini.

\section{DAFTAR PUSTAKA}

Dwi Lestari, N. and Rofiqul Minan, M. (2018). Efektivitas Terapi Wudhu Menjelang Tidur terhadap Kualitas Tidur Remaja', Mutiara Medika: Jurnal Kedokteran dan Kesehatan, 18(2), pp. 49-54. doi:

$10.18196 / \mathrm{mm} .180215$.

El-Bantanie, M. S. (2010) Dasyatnya Terapi Wudhu. Jakarta.

Goel, N., Kim, H. and Lao, R. P. (2005. An olfactory stimulus modifies nighttime sleep in young men and women", Chronobiology International, 22(5), pp. 889-904. doi: 10.1080/07420520500263276.

Goel, N., Kim, H. and Lao, R. P. (2006) „Sleep changes vary by odor perception in young adultse .
Hamzeh, S., Safari-Faramani, R. and Khatony, A. (2020) „Effects of Aromatherapy with Lavender and Peppermint Essential Oils on the Sleep Quality of Cancer Patients: A Randomized Controlled Trial", Evidence-based Complementary and Alternative Medicine, 2020. doi: 10.1155/2020/7480204.

Kushariyadi and Setyoadi (2011) Terapi Modalitas Keperawatan Pada Klien Psikogeriatrik. Jakarta.

Martini, S., Roshifanni, S. and Marzela, F. (2018) „Pola Tidur yang Buruk Meningkatkan Risiko Hipertensi", Media Kesehatan Masyarakat Indonesia, 14(3), p. 297. doi: 10.30597/mkmi.v14i3.4181.

Muslikhatul, U. (2017) „Kualitas Tidur pada Mahasiswa Pondok Pesantren", Journal of Chemical Information and Modeling, p. 28.

Nilifda, H., Nadjmir, N. and Hardisman, H. (2016). Hubungan Kualitas Tidur dengan Prestasi Akademik Mahasiswa Program Studi Pendidikan Dokter Angkatan 2010 FK Universitas Andalas. Jurnal Kesehatan Andalas, 5(1), pp. 243249. doi: 10.25077/jka.v5i1.477.

Nursalam (2017) Metedologi Penelitian Ilmu Keperawatan Pendekatan Praktis. Edisi 4. Jakarta: Salemba Medika.

Putri, D. M. P. and Amalia, R. N. (2019) Terapi Komplementer Konsep Dan Aplikasi Dalam Keperawatan. Yogyakarta.

Ramadhan, M. R. and Zettira, O. Z. (2017). Aromaterapi Bunga Lavender (Lavandula angustifolia) dalam Menurunkan Risiko Insomnia) Fakultas Kedokteran Universitas Lampung, 6, pp. 60-63. 
Sagiran, H. (2018) Gantung Wudhu. Pertama. Edited by H. Jayadi. Jakarta Selatan: Qultum Media.

Sari, D. and Leonard, D. (2018)

„Pengaruh Aroma Terapi Lavender Terhadap Kualitas Tidur Lansia Di Wisma Cinta Kasihee, Jurnal Endurance, 3(1), p. 121. doi: 10.22216/jen.v3i1.2433.

Setyawan, A. (2018). Holistic care nursing II. Yogyakarta.

Setyawan, A. and Oktavianto, E. (2020) 'Efektifitas Aromaterapi Lavender terhadap Tingkat Kecemasan Menghadapi Osce pada Mahasiswa Keperawatan. Jurnal Berkala Kesehatan, 6(1), p. 9. doi: 10.20527/jbk.v6i1.8356. 